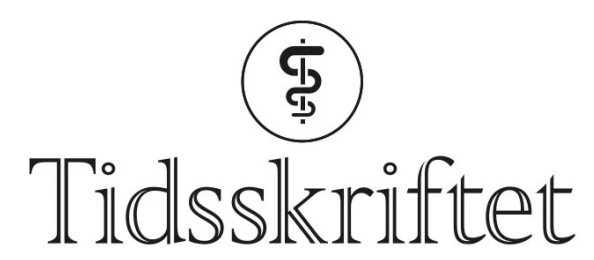

DEN NORSKE LEGEFORENING

\title{
Tid for å utdanne flere leger desentralt
}

DEBATT

\section{INGRID PETRIKKE OLSEN}

ingrid.p.olsen@uit.no

Ingrid Petrikke Olsen er lokal studieleder for Finnmarksmodellen og førsteamanuensis ved Institutt for klinisk medisin, UiT - Norges arktiske universitet.

Forfatteren har fylt ut ICMJE-skjemaet og oppgir ingen interessekonflikter.

\section{$B \varnothing R G E$ LILLEBO}

Børge Lillebo er koordinator for Link NTNU og førsteamanuensis ved NTNU. Forfatteren har fylt ut ICMJE-skjemaet og oppgir ingen interessekonflikter.

\section{EIRIK HUGAAS OFSTAD}

Eirik Hugaas Ofstad er lokal studieleder for Bodøpakken og førsteamanuensis ved Institutt for samfunnsmedisin, UiT - Norges arktiske universitet.

Forfatteren har fylt ut ICMJE-skjemaet og oppgir ingen interessekonflikter.

\section{ARVE $\varnothing S T L Y N G E N$}

Arve Østlyngen er 6. års koordinator i Finnmarksmodellen og universitetslektor ved Institutt for samfunnsmedisin, UiT - Norges arktiske universitet.

Forfatteren har fylt ut ICMJE-skjemaet og oppgir ingen interessekonflikter.

\section{KNUT TORE LAPPEGÅD}

Knut Tore Lappegård er lokal studieleder i Bodøpakken og professor ved Institutt for klinisk medisin, UiT - Norges arktiske universitet.

Forfatteren har fylt ut ICMJE-skjemaet og oppgir ingen interessekonflikter.

\section{Vil en desentralisering av medisinstudiene i Norge styrke utdanningen, avlaste universitetsklinikkene og samtidig øke rekrutteringen til distriktene?}

Forutsetningene for å utdanne leger har endret seg. I takt med at behovet for leger har økt, har de fire medisinerutdanningene i Norge $ø$ kt forsiktig fra opptak av 367 studenter i 1973 til 636 studenter i 2019 (1). Grimstadutvalget har anbefalt en ytterligere opptrapping med 440 studieplasser, med mål om at vi i Norge skal utdanne 80 \% av våre leger selv (1). 
8 o nye studieplasser er nylig tildelt de fire universitetene som har ansvaret for profesjonsutdanningen i medisin (므). Grimstadutvalget anbefaler også at en større del av helsetjenesten - $\mathrm{i}$ hele landet - benyttes som praksisarena.

Å utdanne leger til landsdelen var et av de viktigste argumentene for opprettelsen av UiT Norges arktiske universitet i 1973 (3). I 2009 kom utdanning av 24 studenter på femte og sjette studieår i gang i Bodø. I 2017 utvidet UiT ordningen ved å desentralisere femte og sjette studieår for inntil 12 studenter til Finnmark. I 2018 fulgte NTNU opp med etablering av NTNU Link i Nord-Trøndelag for tredje- og fjerdeårsstudenter (4.).

Det finnes i dag tre desentraliserte studiemodeller i Norge:

\section{Bodøpakken}

En forutsetning for oppstart av desentralisert medisinutdanning ved Nordlandssykehuset Bod $\varnothing$ - kalt Bodøpakken - var at studentene skulle følge identisk timeplan som studentene i Tromsø, men med lokale undervisere fra sykehus og allmennmedisin. Tolv år senere er undervisningen i stor grad lik som i Tromsø. Studentene tas ved studiestart med til en distriktskommune med mer enn 50 års sykestueerfaring, der hovedfokus er hvilke pasienter som må innlegges og hvilke pasienter som kan behandles i kommunal akutt døgnenhet. Temabaserte heldagssimuleringer i akuttmedisin om traume, sepsis, hjertestans og pasienter som blir dårlige på post, ferdighetstrening i ultralyd, kurs i akutt indremedisin og øvelse av større bilulykke i minusgrader langt fra sykehus står sentralt (5).

\section{Finnmarksmodellen}

I Finnmark er spesialisthelsetjenesten geografisk spredt og studentene på femte og sjette studieår roterer derfor mellom Alta, Karasjok og Hammerfest. Studentene har pasientkonsultasjoner i både spesialisthelsetjenesten og kommunehelsetjenesten på alle tre stedene. Læringsmålene er likevel de samme som i Bodø og Tromsø. Som i Bodø får studentene mye undervisning i akuttmedisin, men også generell kulturforståelse og rettigheter og helseutfordringer for den samiske befolkningen. Det er $ø$ kt fokus på gode pasientforløp og samhandling mellom aktører i helsetjenesten og en rekke prøveeksamener. Lokalsykehuset i Hammerfest er hovedbasen slik den også er for sykepleierutdanningen i Finnmark.

\section{NTNU Link}

NTNU Link omfatter tredje og fjerde studieår og er dimensjonert for inntil 16 studenter per studieår. Studentene har base ved Sykehuset Levanger, som sammen med Sykehuset Namsos og kommunehelsetjenesten i regionen er læringsarenaer for studentene. Geografisk nærhet gjør at studentene sporadisk dagpendler til Trondheim og St. Olavs hospital for utvalgt undervisning. Det er etablert et undervisningssamarbeid i akuttmedisinsk simulering med sykepleierutdanningen ved Nord universitet Levanger. Etter fjerde studieår oppfordres studentene til å gjennomføre hovedoppgave og utplasseringsperioder i sykehus og allmennpraksis i samme region.

\section{Flere muligheter ved å desentralisere}

Det er siden oppstart uteksaminert 216 studenter fra Bodøpakken og 33 studenter fra Finnmarksmodellen. Ved NTNU uteksamineres de første våren 2022. Samtidig som disse studentene har fått mye pasientkontakt og undervisning i små grupper, blir 
plassforholdene og gruppestørrelsen bedre for de gjenværende studentene i Tromsø og Trondheim.

\section{«De tre modellene reflekterer $i$ stor grad mulighetene som ligger $i$ desentralisering»}

De tre modellene reflekterer i stor grad mulighetene som ligger i desentralisering. Mens Bodøpakken i 2009 fikk en bestilling om blåkopi av Tromsø, har Finnmarksmodellen i 2017 etablert seg med fokus på å forankre og engasjere både utdanningsmodellen og studentene i lokalsamfunnet, presentere studentene for kulturelle perspektiver, og har generalister som rollemodeller - etter inspirasjon fra Canada (므). NTNU Link benytter det pedagogiske prinsippet om integrert langsgående læring med vekt på studentens kontinuitet med fag, underviser og pasient (7.).

Sykehusene dominerer fortsatt som klinisk læringsarena i alle tre modellene, men kommunehelsetjenesten bidrar også tydelig med allmennleger som gruppeveiledere og med læring ved sykehjem, legevakt, helsestasjon og allmennpraksis. Fra de åtte første kullene som er uteksaminert i Bodø ses en betydelig lokal rekrutteringseffekt, ikke bare til Nordlandssykehuset, men også til allmennmedisin, spesielt til distriktskommuner (slik som beskrevet i artikkelen Leger utdannet $i$ Bodø: hvem er de og hvor blir de av? av Eirik Ofstad, Åsa Westlie, Margrete Gaski, Birgit Abelsen og Hilde Grimstad, under vurdering i Tidsskriftet).

\section{Ønsker mer forskning}

Små fagmiljøer gir mindre forskning. Et godt og integrert samarbeid mellom miljøene ved universitetssykehusene og de desentraliserte modellene er derfor viktig. I dette samarbeidet bør kulturbygging for utdanning og forskning i de desentraliserte miljøene gis oppmerksomhet. Slike tiltak kan bidra til at undervisere - både desentralt og sentralt utvikler seg faglig, profesjonelt og akademisk. Erfaringen fra Bodø er at flere av underviserne har fullført ph.d.-løp som del av bistillingen ved universitetet. I Finnmark er en egen forskningsgruppe nettopp opprettet.

Sentralisering og spesialisering innenfor medisinsk behandling, færre liggedøgn og teknologisk utvikling har medført en endring av pasientpopulasjonen på universitetssykehusene. De vanlige diagnosene og de vanlige pasientene befinner seg i større grad på lokalsykehus, desentraliserte medisinske sentre og $\mathrm{i}$ kommunehelsetjenesten. Folk skader seg og blir akutt syke i sitt lokalsamfunn. Denne endringen i hvor, hvordan og fra hvem pasienten i dag mottar helsetjenester må de helsefaglige utdanningsinstitusjonene henge med på, og utformingen av studieprogrammer må plasseres inn i dette terrenget. Det vanlige og det farlige kan læres godt utenfor universitetssykehus.

\section{Sterkere fokus internasjonalt}

It takes a village to raise a medical student (ㅁ). Nye stemmer har nå tatt til orde for i større grad å flytte deler av utdanningen ut fra de fire universitetsbyene med sine tilhørende universitetssykehus, og til lokalsykehus og kommune. I internasjonal litteratur finner vi god støtte for at dette gir fordeler $(9, \underline{10})$. 
«Ved å eksponere studenter for variasjonen i hverdagslige kliniske

problemstillinger blir den nyutdannede legen godt rustet for legeyrket, uansett valg av videre yrkeskarriere»

Det er med andre ord mange gode grunner til at desentraliserte studiemodeller i medisinsk utdanning må hilses velkommen. Ved å eksponere studenter for variasjonen i hverdagslige kliniske problemstillinger blir den nyutdannede legen godt rustet for legeyrket uansett valg av videre yrkeskarriere. Om en desentralisering i tillegg $ø$ ker rekrutteringen til distriktene blir universitetenes samfunnsoppdrag enda tydeligere.

\section{LITTERATUR}

1. Grimstadutvalget. Studieplasser i medisin i Norge. Behov, modeller og muligheter. Stavanger: Kunnskapsdepartementet, 2019. https://regjeringen.no/contentassets/9b5b81d102384507b8515of2eofibo89/117459oo_rapport_utredni ng_fra_grimstadutvalget.pdf Lest 23.6.2021.

2. Regjeringen. Utdanningsløftet 2020: Her kommer de nye studieplassene. https://www.regjeringen.no/no/aktuelt/utdanningsloftet-202o-her-kommer-de-nyestudieplassene/id2703859/ Lest 23.6.2021.

3. Aaraas IJ, Halvorsen PA, Aasland OG. Supply of doctors to a rural region: Occupations of Troms $\varnothing$ medical graduates 1979-2012. Med Teach 2015;37:1078-82. [PubMed][CrossRef]

4. Link NTNU. https://www.ntnu.no/blogger/link/ Lest 23.6.2021.

5. Skodvin KG. Kan legestudenter lære akuttmedisin i en kommune? Utposten 2020, nr. 3. https://www.utposten.no/journal/2020/3/m-

642/Kan_legestudenter_l\%C3\%A6re_akuttmedisin_i_en_kommune? Lest 23.06.21

6. Hays RB, Strasser RP, Sen Gupta TK. Twelve tips for establishing a new medical school. Med Teach 2020; 42:398-402. [PubMed][CrossRef]

7. Hirsh DA, Ogur B, Thibault GE et al. "Continuity" as an organizing principle for clinical education reform. N Engl J Med 2007; 356: 858-66. [PubMed][CrossRef]

8. Morgan RC. It takes a village to raise a medical student. J Natl Med Assoc 1997; 89: 82-4.

9. de Villiers M, van Schalkwyk S, Blitz J et al. Decentralised training for medical students: a scoping review. BMC Med Educ 2017; 17: 196. [PubMed][CrossRef]

10. Strasser R. Learning in context: education for remote rural health care. Rural Remote Health 2016; 16: 4033. [PubMed]

Publisert: 20. juli 2021. Tidsskr Nor Legeforen. DOI: 10.4045/tidsskr.21.0367

Mottatt 30.4.2021, første revisjon innsendt 23.6.2021, godkjent 30.6.2021.

(C) Tidsskrift for Den norske legeforening 2023. Lastet ned fra tidsskriftet.no 26. april 2023. 